\title{
Effect of treatment modes on quality and antioxidant properties of tomato and beet processing products
}

\section{Zhanna Petrova ${ }^{1}$, Vadim Pazyuk ${ }^{1}$, Kateryna Samoilenko ${ }^{1}$, Olena Chepeliuk ${ }^{2}$}

\author{
1 - Institute of Engineering Thermophysics, National Academy of Sciences of Ukraine, \\ Kyiv, Ukraine \\ 2 - National University of Food Technologies, Kyiv, Ukraine
}

\section{Keywords: \\ Seed \\ Tomato \\ red beet \\ Drying \\ Germinability \\ Betanin}

\section{Article history: \\ Received \\ 05.04.2018 \\ Received in \\ revised form \\ 29.05.2018 \\ Accepted \\ 29.06.2018 \\ Corresponding author: \\ Olena Chepeliuk \\ E-mail: \\ lenasandul@ \\ yahoo.com}

DOI:

$10.24263 / 2304-$ 974X-2018-7-2-12

\section{Abstract}

Introduction. The research was conducted to substantiate the rational drying conditions of tomato seeds. The ratio and drying conditions of the composition from tomato waste with the addition of red beet were substantiated.

Materials and methods. The tomato seeds were prepared according to the traditional methodology used in the industry. From red beet and tomato waste compositions with the ratios of components 4:1, 3:1, 2:1, 1:1 were created. Tomato seeds have been dried using the convective method at the air temperature $\mathrm{t}=$ $50-80^{\circ} \mathrm{C}$, as well as the composition from red beets and pulp of tomatoes - at $\mathrm{t}=60-100{ }^{\circ} \mathrm{C}$. The quality of dried seeds was estimated on the basis of its germinability, dried mixtures - on the content of betanin in them.

Results and discussion. When the temperature of the air increases, the intensity of tomato seeds drying increases too. Thus, the drying time reduces by 2.5 times when the air temperature is raised from 50 to $80^{\circ} \mathrm{C}$. However, qualitative seed material, which gives the germinability of $98 \%$, has been attained at the drying temperature of $50^{\circ} \mathrm{C}$.

Non-waste processing of tomatoes involves the creation of compositions of pulp tomatoes and sliced red beets, their drying, grinding and packing. In industrial conditions, red beets need to be cut into chips, which intensifies the drying process of the composition. The slicing of tomatoes in compositions does not affect the process speed.

When the air temperature increases from 60 to $100{ }^{\circ} \mathrm{C}$, the intensity of compositions drying is raised by 1,8 times. Maximum preservation of the useful substances in the finished product results from the choice of a soft drying condition and an air temperature of $60^{\circ} \mathrm{C}$.

$\mathrm{pH}=3.9$ is characteristic for the ratio of red beet-tomato components $3: 1$ in composition, which ensures the maximum preservation of betanin $(94.7 \%)$ at drying.

Conclusions. The heat carrier temperature substantially affects the tomato seeds germinability and antioxidant properties of tomato and beet processing products. 


\section{Introduction}

Nowadays, the need to substantiate the optimal conditions of energy-efficient nonwaste technological processes of seeds drying for sowing and complete processing of vegetables requires complex theoretical and experimental research.

There is a risk of shelf life reduction if the moisture content in the seeds is either too high or too low at storage [1]. At high moisture content in the seeds, the processes of metabolism and its breathing are sharply increased [2].

There is a low germinability in freshly collected seeds of many vegetables and flowers, they need a post-harvest maturation. Tomatoes at high humidity have the ability to sprout immediately after harvesting. Therefore, determining the modes of tomato seeds drying, which provide the required quality of seed material over a given time, is an urgent task.

There are not so many scientific works on the drying of tomato seeds. Most thoroughly this problem was examined by Sogi D.S., Shivhare U.S., Garg S.K., Bawa A.S. [3] who investigated the drying of tomato seeds in cabinet/fluidised bed driers, but the effect of drying conditions on the quality of the seeds was not mentioned.

The problem of processing of tomato pulp, which remains after removing the seed material is important too.

Tomato products have a promising potential as functional food for liver health. Tomato extracts and pure compounds are able to decrease the reactive oxygen species (ROS) generation of HepG2 cells, the phenolic compounds being more effective than lycopene [4]. Consumption of tomatoes has oncoprophylaxis and antioxidant effects, the condition of the cardiovascular system improves.

Another very useful vegetable is a red beet. Anthocyanin colorants, catechins, flavonol glycosides, vitamins, minerals contained in beets help cleanse the body, lower cholesterol levels in the blood, improve a fat metabolism, strengthen capillaries and blood vessels, promote hematopoiesis, increase hemoglobin content and increase the amount of erythrocytes, prevent oncological diseases, reduce blood pressure [5].

Betalains contained in red beet in vacuoles of cells are water soluble pigments that were previously referred to as anthocyanins. However, betalains are structurally and chemically different from the anthocyanins and have never been detected in the same plant simultaneously with them [6]. It is now known that betalains are aromatic indole compounds that are synthesized from tyrosine. They are not chemically similar to anthocyanins, as well as flavonoids [7]. Each betalain is a glycoside containing sugar and a dye component [8]. Important among betalains is betanin, which is glycoside. In the industry betanin, made from red beet, is used as a food colorant [9].

Vegetables contain a large amount of moisture (in some cases up to $95 \%$ ), they are unstable when stored and their losses can reach up to $50 \%$. So, it is important to create the proper conditions for their storage. According to statistics in the world about $20 \%$ of fruits and vegetables are dried [10]. At that different methods are used [11]: convective [12], vacuum [13], infrared [14], microwave drying [15], osmotic dehydration, freeze-drying, closed loop heat pump dryer [16], combined drying methods.

The production of dry fruits and vegetables and their powders is a promising direction [17]. As a result of industrial processing of tomatoes, in particular drying, it is necessary to preserve maximum useful substances and antioxidant potential [18 - 22], so many studies are aimed at determining the rational conditions of dehydration $[23 ; 24]$ that can provide the quality of the finished product.The content of ascorbic acid in tomatoes after drying, which is the least stable component to the thermal effect [24], the moisture diffusivity and activation energy, color parameters, chemical composition [25], including the content of 
lycopene [26], taste were considered as quality indices in previous studies. For beet it is, first of all, the betanine content [27].

In addition to the temperature, the size of the particles of the drying material should also has been included to the drying conditions. This is relevant both for the drying of tomatoes [28], beets [29], and mixtures thereof. There is also a requirement for drying in a thin layer [30].

The purpose of the research is to substantiate the drying conditions of tomato seeds and compositions based on red beet and tomato waste, as well as content of composition, in which, after thermal treatment, the maximum content of betanin and antioxidant properties are preserved.

\section{Materials and methods}

\section{Preparation of tomato seeds for drying}

To obtain high quality seeds, ripe and intact plum tomatoes were harvested in the middle of bearing of shrubs. The pulp of tomato prevents seeds from germination, and in damaged vegetables the seeds may germinate prematurely even during the drying process at low temperatures. The selected tomatoes were washed, cut and seeds were separated from the main pulp. The seeds fermented in tomato juice at an ambient temperature of $25{ }^{\circ} \mathrm{C}$ throughout the two days. After that, the liquid was drained and the seeds remaining on the bottom of the container were washed several times with water and supplied for drying [2].

\section{Creation of beet-tomato composition [31]}

After removal of tomato seeds a large quantity of pulp remains, therefore the technology of their use was offered for the purpose of creating beet-tomato composition, which has therapeutic and prophylactic, in particular antioxidant, properties.

To obtain an antioxidant powder, a composition of tomatoes and beets was created in appropriate ratios, dried below equilibrium humidity, cooled to ambient temperature, crushed, sifted and packed in kraft bags.

The size and shape of the material substantially affect the kinetics of the drying process. To create the composition, tomatoes was cut into slices $5 \times 5 \times 5 \mathrm{~mm}$ and red beet into chips $2 \times 5 \times 2 \mathrm{~mm}$ and plates $5 \times 5 \times 2 \mathrm{~mm}$. The size of tomatoes was kept constant. The effect of the size of the crushed beet on the drying process was studied because its content in the composition is greater.

\section{Research of drying kinetics}

Studies on determining the drying kinetics of tomato seeds, as well as vegetable compositions of beet-tomato, were carried out on a test bench of convective drying equipped with an automatic system for processing and collecting information that allows more accurately characterize the drying process with the construction of graphic dependences [32].

The tomato seeds were dried in a layer of thickness $\delta=10 \mathrm{~mm}$ at a velocity of the air $\mathrm{V}$ $=1.5 \mathrm{~m} / \mathrm{s}$ (the speed was chosen from the condition of more effective drying of the same material in existing modern dryers [33]) at a temperature $\mathrm{t}=50-80{ }^{\circ} \mathrm{C}$ to equilibrium moisture content $8 \%$, and compositions of beets and tomatoes pulp - at the air speed $\mathrm{V}=$ 
$3,5 \mathrm{~m} / \mathrm{s}$ and in the temperature range of the air from $60 \mathrm{C}$ to $100{ }^{\circ} \mathrm{C}$ to a residual moisture content of 3,0\%. The drying processes lasted $12-100 \mathrm{~min}$.

\section{Determination of the germinability of tomato seeds}

The germinability of tomato seeds after different drying conditions was analyzed at $20{ }^{\circ} \mathrm{C}$ for 7 days, determining the percentage of sprouted seeds [2].

\section{Evaluation of the quality of dried beet-tomato compositions}

The quality of the dried compositions was evaluated according to the content of betanin, which should be preserved as much as possible as compared to the raw material. The content of betanin in beet-tomato composition depends on its acidity. The method for determining the betanin content in the compositions is given in detail in [31].

\section{Results and discussion}

As the air temperature increases, the intensity of the drying process of the tomato seeds increases (Figure 1). Thus, drying at $50^{\circ} \mathrm{C}$ is a long process and takes 30 minutes, which is 2.5 times more than the drying time at a temperature of $80^{\circ} \mathrm{C}$.

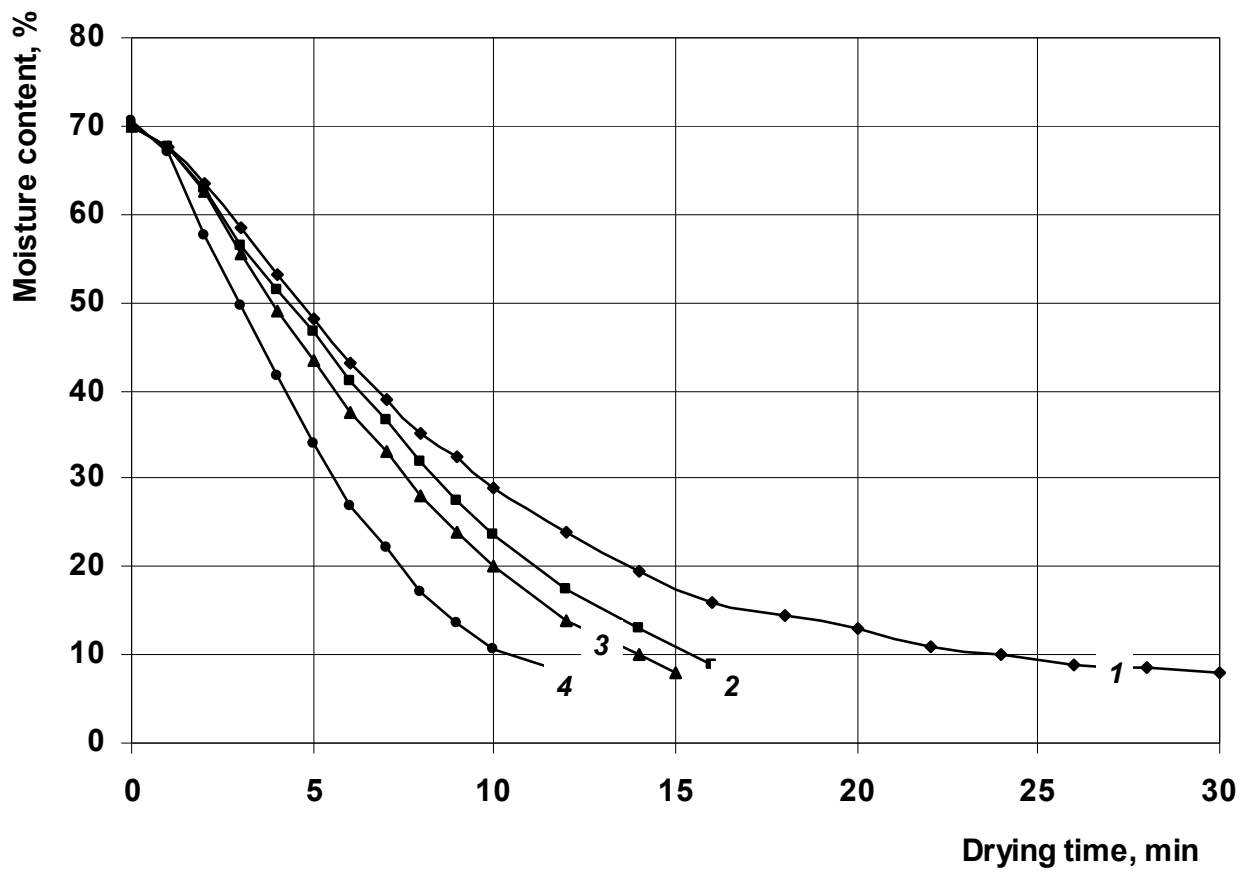

Figure 1. Effect of the air temperature on the drying kinetics of tomato seeds, $V=1,5 \mathrm{~m} / \mathrm{c}, \delta=10 \mathrm{mм}:$

$1-50^{\circ} \mathrm{C} ; 2-60^{\circ} \mathrm{C} ; 3-70^{\circ} \mathrm{C} ; 4-80^{\circ} \mathrm{C}$ 
However, it is the quality of the seed material rather than the duration of drying that determines the choice of rational temperature of the air. The quality of the seeds is determined by its ability to sprout.

The air temperature significantly affects this index (Figure 2).

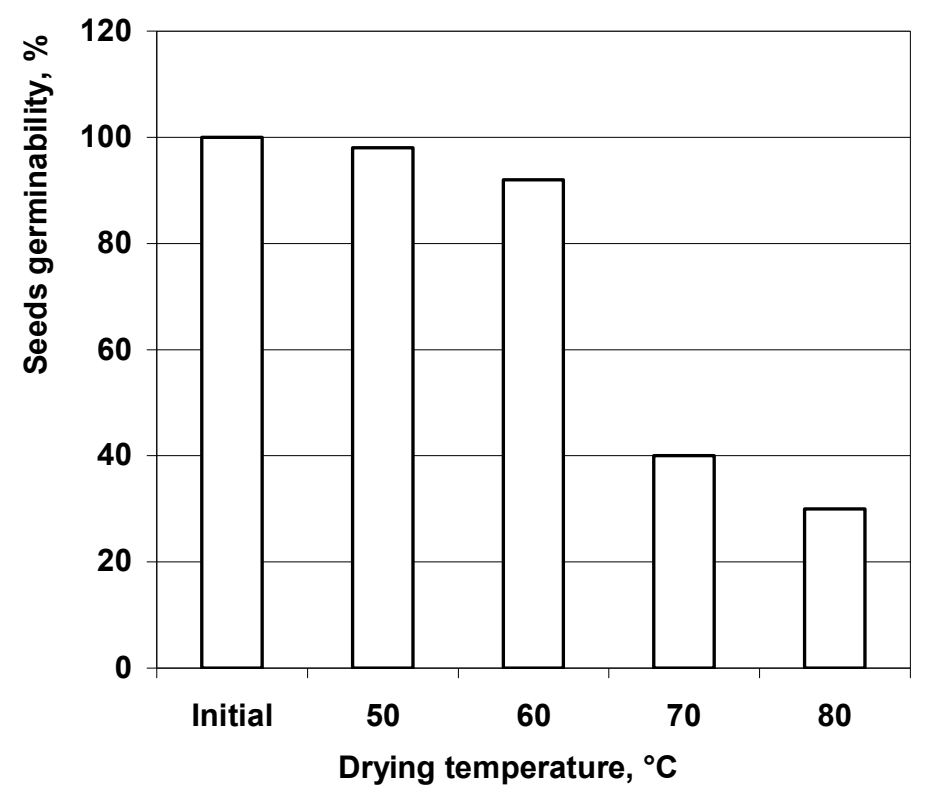

Figure 2. Germination of tomato seeds from the drying condition

The temperature of $60{ }^{\circ} \mathrm{C}$ gives the seed germinability at the level of $92 \%$ of the initial seed germinability. The rational condition of tomato seeds drying is the air temperature of $50{ }^{\circ} \mathrm{C}$, the germinability at which is $98 \%$.

Five samples with different contents of the components were investigated to determine the required ratio of components of beet-tomato composition with optimum $\mathrm{pH}$, which results in a high percentage of betanine preservation. At $\mathrm{pH} 3-4$ maximum betanin is preserved during heat treatment. As can be seen from Figure 3, the required $\mathrm{pH}$ level is characteristic for the ratio of three parts of red beet and one part of tomato. It was this composition that was used in further research.

The drying kinetics of beet-tomato composition with the change in the size of the cut beet into the chips $2 \times 5 \times 0.2 \mathrm{~mm}$ and into the plate $5 \times 5 \times 2 \mathrm{~mm}$ (figure 4 ) was studied.

As can be seen from Figure 3, the duration of drying the composition with red beets, cut into chips, is 78 minutes, and into the plate is 100 minutes.

The curves of drying the beet-tomato composition (Figure 5) show that the drying process occurs in falling-rate period, no constant-rate period of drying was observed. This is due to the peculiarities of composite raw materials. 


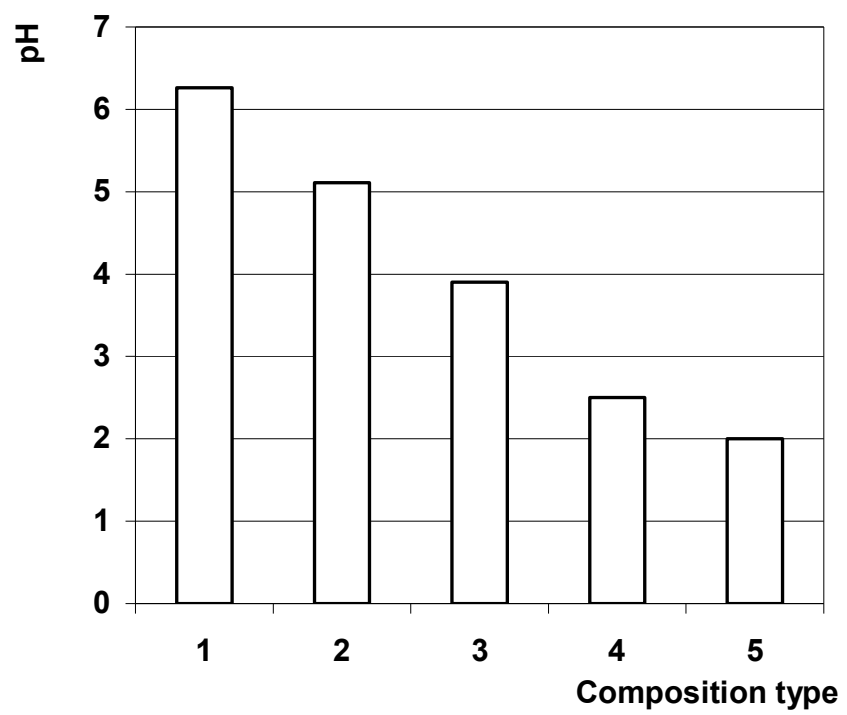

Figure 3. The $\mathrm{pH}$ of the composition depending on the ratio of components: 1 - red beet; 2 - beet-tomato (4: 1$) ; 3$ - beet-tomato (3:1); 4 - beet-tomato $(2: 1) ; 5$ - beet-tomato $(1: 1)$

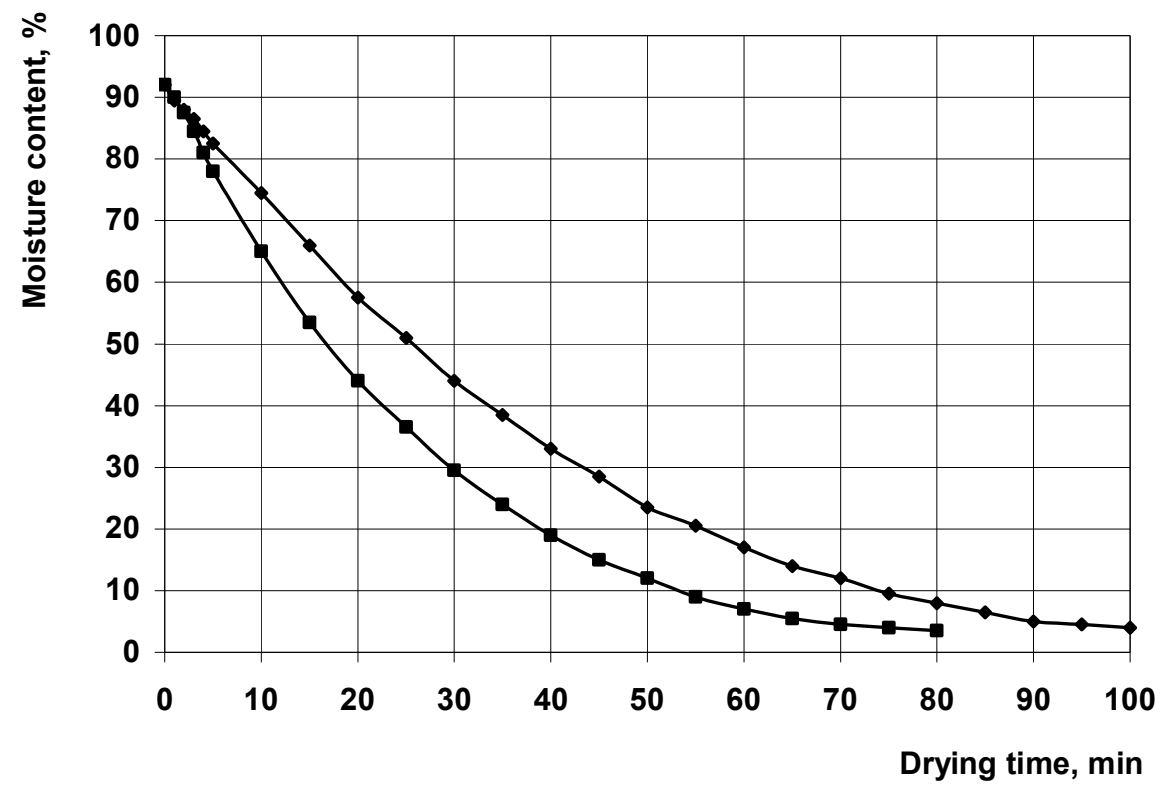

Figure 4. Effect of cutting beets on the drying kinetics of the composition red beet-tomato $(3: 1) \mathrm{t}=60^{\circ} \mathrm{C}, \mathrm{V}=3.5 \mathrm{~m} / \mathrm{s}, \delta=10 \mathrm{~mm}$ : 1 - plate; 2 - chips. 


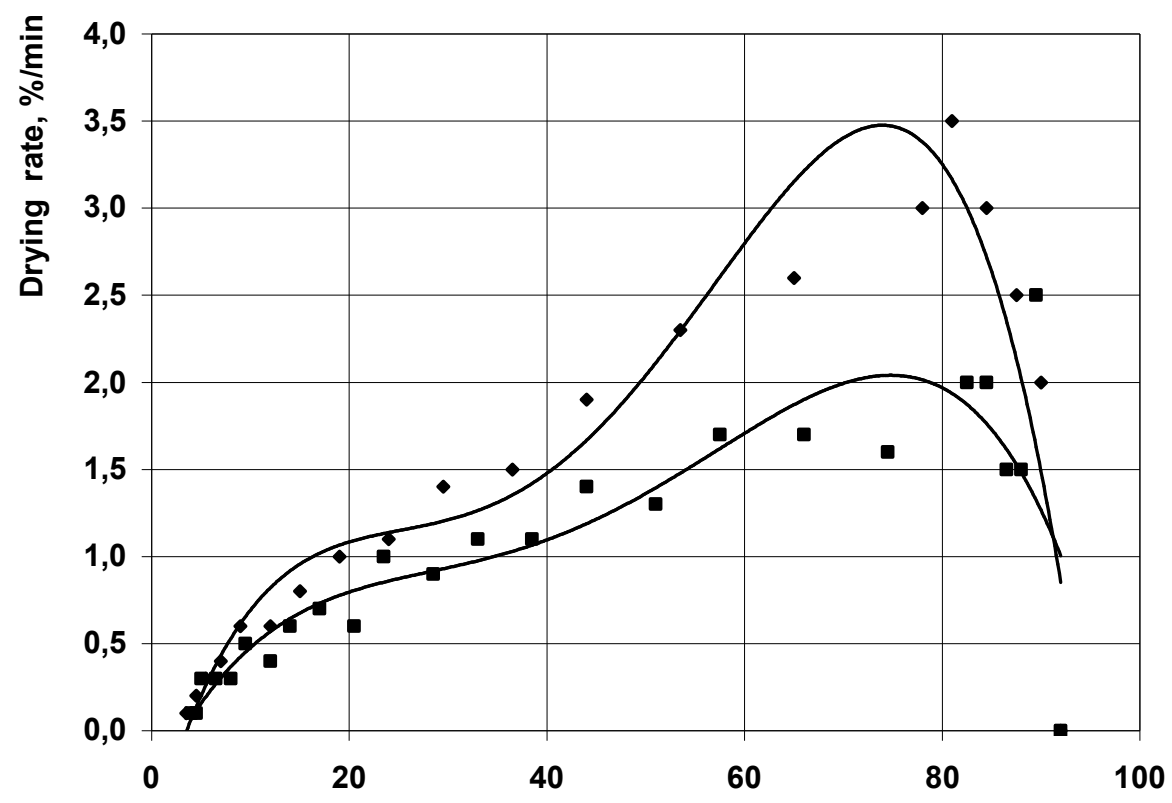

Moisture content, \%

Figure 5. Effect of beets cutting on the drying speed of the composition red beet - tomato (3: 1) $\mathrm{t}=60^{\circ} \mathrm{C}, \mathrm{V}=3,5 \mathrm{~m} / \mathrm{s}, \delta=10 \mathrm{~mm}$ :

1 - plate; 2 - chips.

As the results show, the drying process of the composition with beets, cut into chips, is more intense than with those cut into plate, and the kind of slicing of tomato in the composition does not affect the speed of the process. Therefore, to intensify the drying process in industrial conditions, the red beet in the composition must be cut into chips.

The air temperature changes the drying kinetics of the beet-tomato composition (Figure 6 ) and the drying rate (Figure 7).

The curves have the appearance typical of colloidal capillary-porous materials. With the increase in the air temperature, the intensity of the drying process of the composition increases. The duration of the process reduces by 1.8 times when the air temperature is raised from 60 to $100{ }^{\circ} \mathrm{C}$. At an air temperature $60^{\circ} \mathrm{C}$, the drying time is 100 minutes. However, the need to preserve as much as possible the useful substances in the finished product causes the choice of a soft drying condition and the air temperature $60^{\circ}$.

As the temperature rises, the material is heated more rapidly and the free moisture is removed faster, as a result of which the first critical drying point is shifted to the left. 


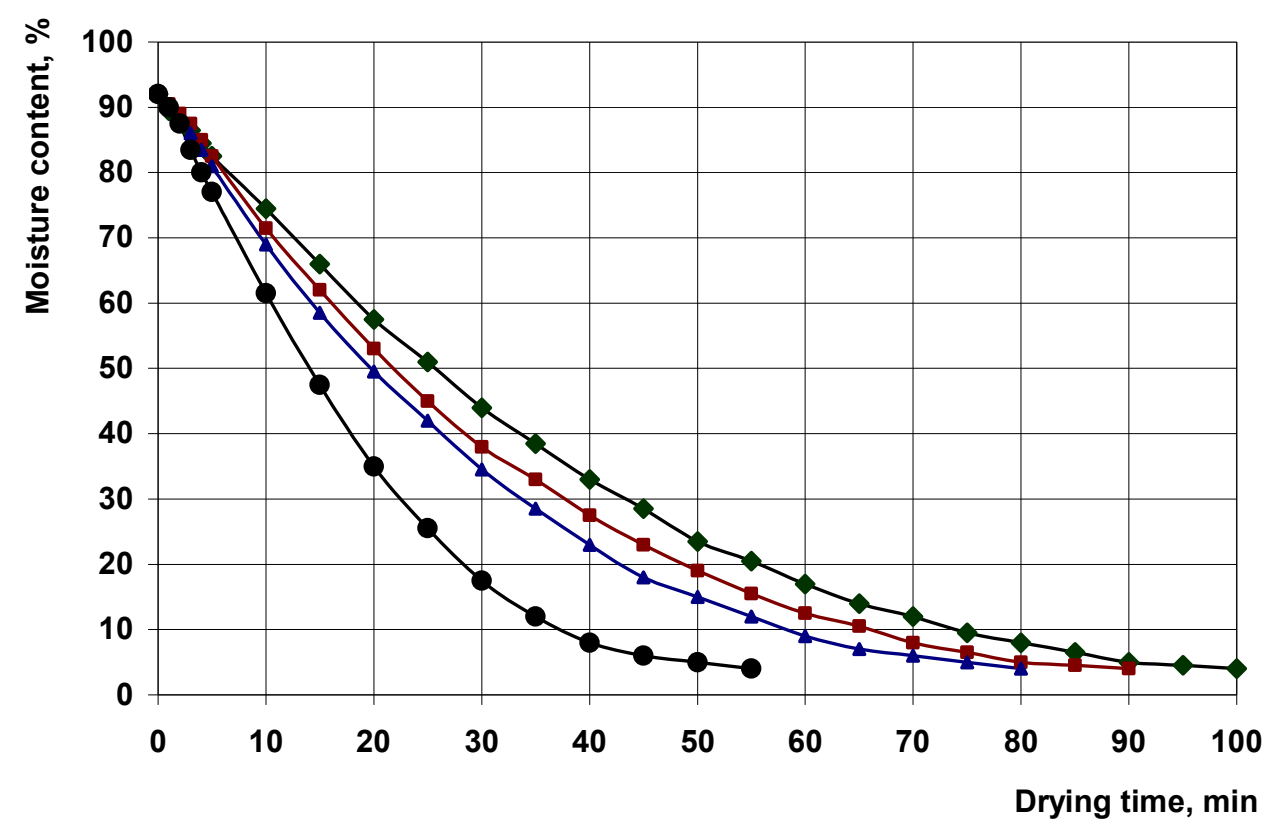

Figure 6. Effect of the air temperature on the drying kinetics of the red beet-tomato composition (3: 1) $\mathrm{V}=3.5 \mathrm{~m} / \mathrm{s}, \delta=10 \mathrm{~mm}$ :

$1-60{ }^{\circ} \mathrm{C} ; 2-70^{\circ} \mathrm{C} ; 3-80{ }^{\circ} \mathrm{C} ; 4-100{ }^{\circ} \mathrm{C}$.

동

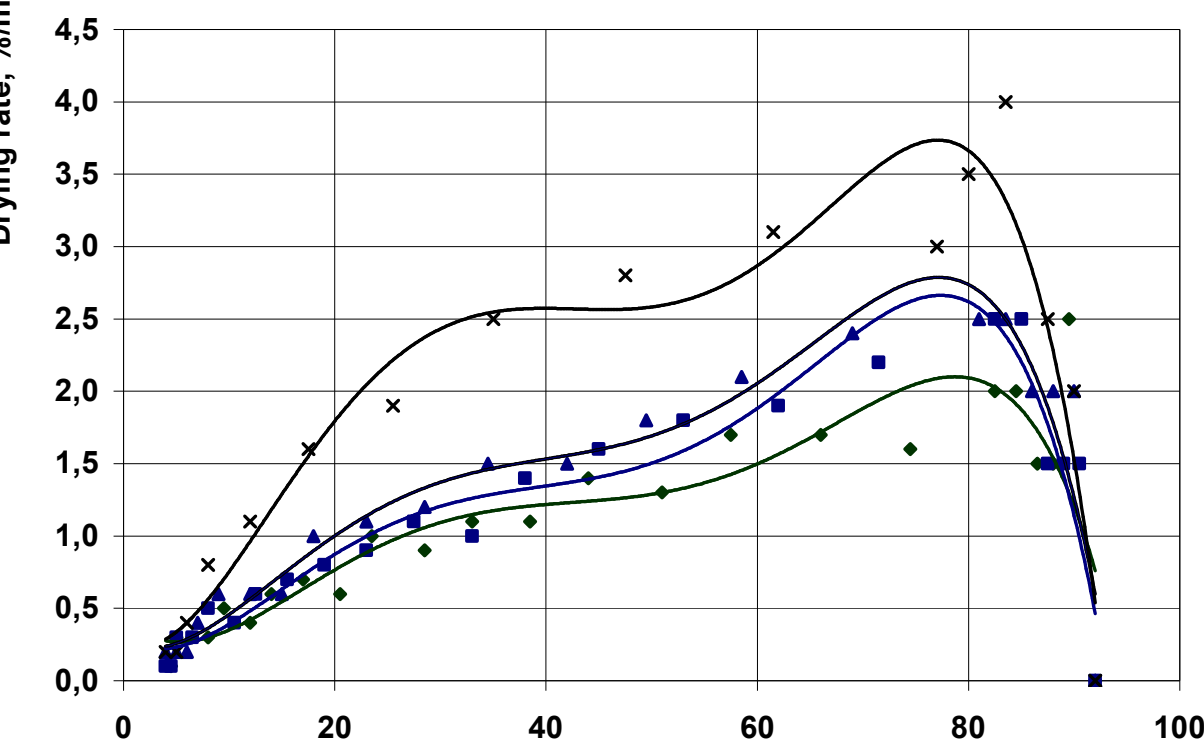

Moisture content, \%

Figure 7. Effect of the air temperature on the drying rate of the composition red beet-tomato $(3: 1), V=3,5 \mathrm{~m} / \mathrm{s}, \delta=10 \mathrm{~mm}$ : $1-60{ }^{\circ} \mathrm{C} ; 2-70{ }^{\circ} \mathrm{C} ; 3-80{ }^{\circ} \mathrm{C} ; 4-100{ }^{\circ} \mathrm{C}$. 
The effect of the composition components on the drying kinetics is shown in Figure 8.

The initial humidity of the components is different, it is the largest in tomato, the drying time of which is respectively 130 minutes, the duration of drying of beet is 85 minutes, and of the composition is 100 minutes.

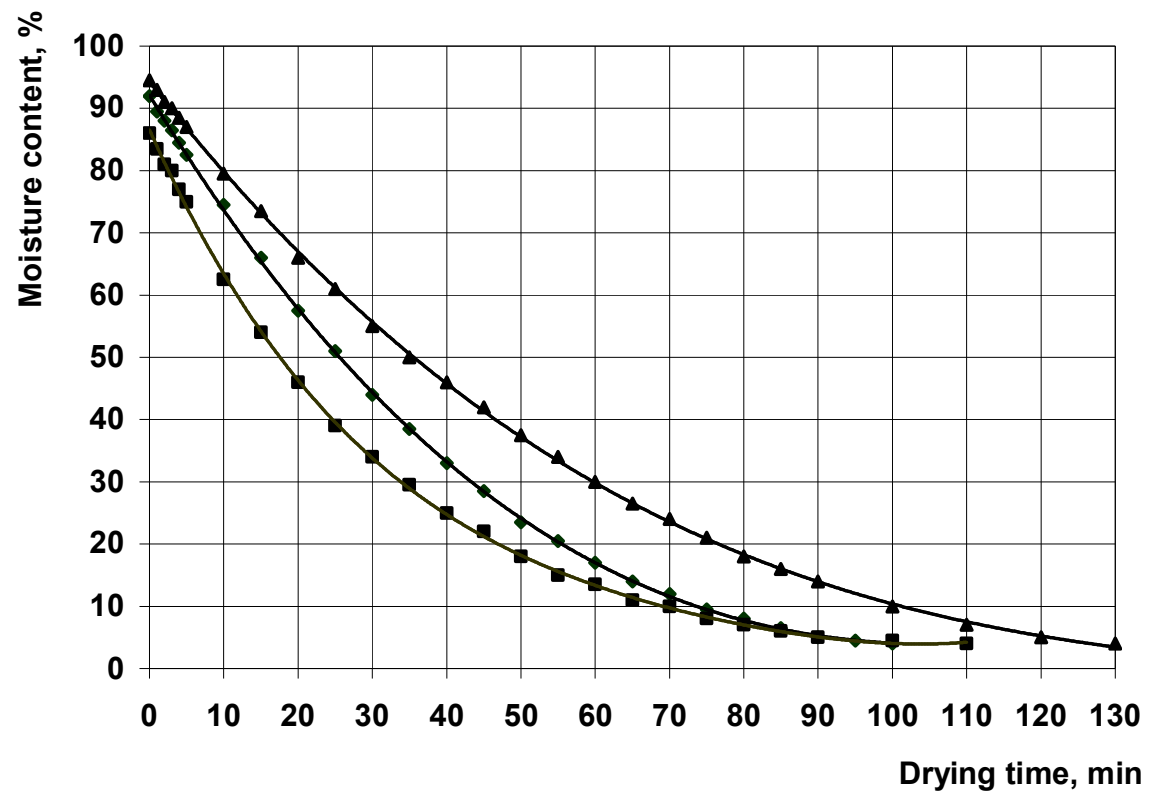

Figure 8. Influence of composition components on drying kinetics $\mathrm{t}=60^{\circ} \mathrm{C}, \mathrm{V}=3,5 \mathrm{~m} / \mathrm{s}, \delta=10 \mathrm{~mm}$ :

1 - beet-tomato (3: 1), 2 - tomato; 3 - red beet

From the curves of the drying speed of the composition components and the composition itself (Figure 9) it is evident that at the beginning of the drying process, the highest drying rate in beet is $2.8 \% / \mathrm{min}$, the lowest in tomatoes $-1.6 \% / \mathrm{min}$, for the composition its value is equal to $2.2 \%$ / min. The second period of drying is characterized by slowing down the drying rate of beet, and for a composition after reaching a moisture content of $35 \%$, the process is quickened and the moisture evaporates intensively.This is due to the influence of organic acids of tomato on the cellular shell of red beet.

The main requirement for beet-tomato composition is the conservation of betanin during the processing of raw materials. The drying of red beet itself destroys betanin by almost $62 \%$ (Figure 10), while the combination of red beet with tomato waste after the removal of seeds retains a high content of betanine after drying. Its maximum content is $94.7 \%$ at an air temperature $60{ }^{\circ} \mathrm{C}$ and at a ratio of components 3: 1 , which is due to the optimum $\mathrm{pH}$ value of the composition (see Figure 3). 


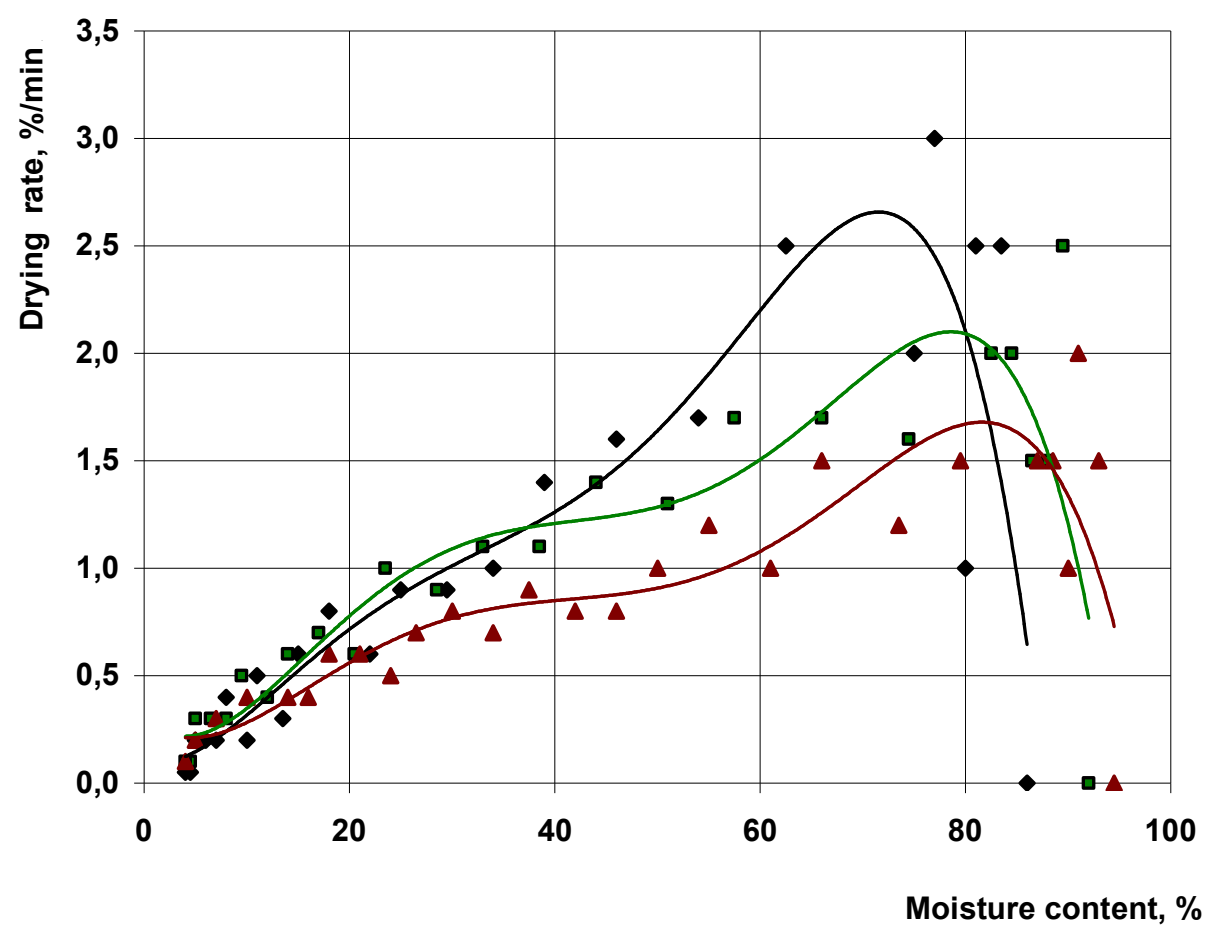

Figure 9. Influence of the composition components on the drying rate $\mathrm{t}=60^{\circ} \mathrm{C}, \mathrm{V}=3,5 \mathrm{~m} / \mathrm{s}, \delta=10 \mathrm{~mm}$ :

1 - red beet; 2 - beet-tomato (3: 1); 3 - tomato

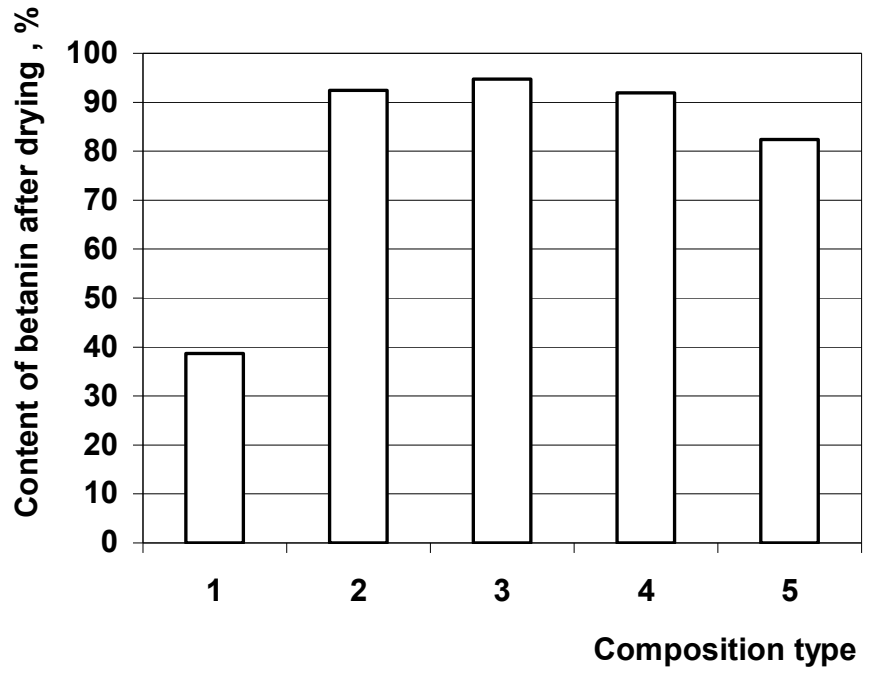

Figure 10. Influence of compositions type on the content of betanin after drying at $\mathrm{t}=60{ }^{\circ} \mathrm{C}$ : 1 - red beet; 2 - beet-tomato (4: 1$) ; 3$ - beet-tomato (3:1) 4 - beet-tomato (2: 1); 5 - beet-tomato (1:1) 


\section{Conclusions}

The waste-free technology of tomatoes processing involves the production of seeds and the use of tomato pulp to produce antioxidant powder based on beets and tomatoes. When using the convection method of drying 10-mm-thick layer:

1. The greatest germinability of tomato seeds ( $98 \%$ in comparison with untreated) is provided at air temperature of $50^{\circ} \mathrm{C}$.

2. Maximum preservation of the useful substances and antioxidant properties of the composition based on the waste of tomato and beet is achieved at a soft drying at air temperature of $60^{\circ} \mathrm{C}$.

3. For the composition with the ratio of red beet and tomato components $3: 1$, the $\mathrm{pH}$ is 3.9 , which results in a high level of betanin content preservation $(94.7 \%)$ at heat treatment.

The novelty of the scientific research consists in obtaining new experimental data on the influence of drying conditions on the quality indices of tomato seed and the quality and antioxidant properties of tomato and red beet products.

\section{References}

1. (2006) The effects of storage conditions on seed shelf life, Seed technical bulletin, May, Available at: https://www.seedquest.com/id/r/rogers/pdf/seedstorage.pdf

2. Liuta Yu.O., Kosenko N.P. (2012), Optymizatsiia rezhymiv vysushuvannia nasinnia tomata, Ovochivnytstvo i bashtannytstvo, 58, pp. 217-221.

3. Sogi D.S., Shivhare U.S., Garg S.K., Bawa A.S. (2003), Water sorption isotherm and drying characteristics of tomato seeds, Biosyst. Eng., 84 (3), pp. 297-301.

4. Navarro-González I., García-Alonso J., Periago M.J. (2018), Bioactive compounds of tomato: Cancer chemopreventive effects and influence on the transcriptome in hepatocytes, Journal of Functional Foods, 42, pp. 271-280.

5. Sniezhkin Yu.F., Petrova Zh.O., Samoilenko K.M., Mykhailyk V.A. (2017), Deryvatohrafichne doslidzhennia znevodnennia betaninovmisnykh roslynnykh materialiv ta yikh termichnoi stiikosti, Naukovi pratsi ONAKhT, 80 (1), pp. 30-35.

6. Bär A., Borrego F., Castillo J., del Rio J. A. (1990), Neohesperidine dihydrochalcone: Properties and applications, Lebensm. Wiss. Technol., 23, pp. 371.

7. Letícia Christina Pires Gonçalves, Marco Aurélio de Souza Trassi, Nathana Barbosa Lopes, Felipe Augusto Dörr, Monica Teixeira dos Santos, Wilhelm Josef Baader, Vani Xavier Oliveira Jr., Erick Leite Bastos(2012), A comparative study of the purification of betanin, Food Chemistry, 131 (1), pp. 231-238.

8. Branen A.L., Davidson P.M., Salminen S. (1990), Food Additives, Marcel Dekker, NewYork.

9. Guesmi A., Ladhari N., Ben Hamadi N., Sakli F. (2012), Isolation, identification and dyeing studies of betanin on modified acrylic fabrics, Industrial Cropsand Products, 37 (1), pp. 342 346.

10. Min Zhang, Bhesh Bhandari, Zhongxiang Fang (2017), Handbook of Drying of Vegetables and Vegetable Products, CRC Press, Boca Raton.

11. Gaware T.J., Sutar N., Thorat B.N. (2010), Drying of tomato using different methods: comparison of dehydration and rehydration kinetics, Dry. Technol., 28, pp. 651-658.

12. Bennamoun L, Khama R., Léonard A. (2015), Convective drying of a single cherry tomato: Modeling and experimental study, Food and Bioproducts Processing, 94, pp. 114-123.

13. Rajkumar P., Kulanthaisami S., Raghavan G.S.V., Gariepy Y., Orsat V. (2007), Drying kinetics of tomato slices in vacuum assisted solar and open sun drying methods, Dry. Technol., 25 (7), $1349-1357$.

14. Ruiz Celma A., Cuadros F., López-Rodríguez F. (2009), Characterisation of industrial tomato by-products from infrared drying process, Food and Bioproducts Processing, 87, pp. 282-291. 
15. Zhang M, Tang J, Mujumdar A, Wang S. (2006), Trends in microwave related drying of fruits and vegetables, Trends in Food Science and Technology, 17, pp. 524-534.

16. Coskun S., Doymaz I., Tunçkal K., Erdogan S. (2016), Investigation of drying kinetics of tomato slices dried by using a closed loop heat pump dryer, Heat and Mass Transfer, 53, pp.1863-1871.

17. Karam M.C.E., Petit J., Zimmer D., Djantou E.B., Scher J. (2016), Effects of drying and grinding in production of fruit and vegetable powders: a review, J. Food Eng., 188, pp. 32-49.

18. Dewanto V., Wu X., Adom K.K., Liu R.H. (2002), Thermal processing enhances the nutritional value of tomatoes by increasing total antioxidant activity, J. Agric. Food Chem., 50, pp. 30103014.

19. Gumusay O.A., Borazan A.A., Ercal N., Demirkol O. (2015), Drying effects on the antioxidant properties of tomatoes and ginger, Food Chemistry, 173, pp. 156-162.

20. Kamiloglu S. (2016), A review on the effect of drying on antioxidant potential of fruits and vegetables, Critical Reviews in Food Science and Nutrition, 56, pp. 110-129.

21. Capanoglu E., Beekwilder J., Boyacioglu D., De Vos R.C., Hall R.D. (2010), The effect of industrial food processing on potentially health-beneficial tomato antioxidants, Critical Reviews in Food Science and Nutrition, 50, pp. 919-930.

22. Azeez L., Adeoye M.D., Majolagbe T.A., Lawal A.T., Badiru R. (2012), Antioxidant activity and phytochemical contents of some selected Nigerian fruits and vegetables, Am. J. Chem., 2 (4), pp. 209-213.

23. Luqmon Azeez, Segun A. Adebisi, Abdulrasaq O. Oyedeji, Rasheed O. Adetoro, Kazeem O. Tijani (2017), Bioactive compounds' contents, drying kinetics and mathematical modelling of tomato slices influenced by drying temperatures and time, Journal of the Saudi Society of Agricultural Sciences, DOI: 10.1016/j.jssas.2017.03.002.

24. Marfil P. H. M., Santos E. M., Telis V. R. N. (2008), Ascorbic acid degradation kinetics in tomatoes at different drying conditions, LWT - Food Science and Technology, 41, pp. 1642 1647.

25. Jorge A., Almeida D.M., Canteri M.H.G., Sequinel T., Kubaski E.T., Tebcherani S.M. (2014), Evaluation of the chemical composition and colour in long-life tomatoes (Lycopersicon esculentum Mill) dehydrated by combined drying methods, International Journal of Food Science \& Technology, 49, pp. 2001-2007.

26. Shi J., Maguer M.L. (2000). Lycopene in tomatoes: chemical and physical properties affected by food processing, Critical Reviews in Food Science and Nutrition, 40, pp. 1-42.

27. Wiczkowski W., Romaszko E., Szawara-Nowak D., Mariusz K. Piskula (2018), The impact of the matrix of red beet products and interindividual variability on betacyanins bioavailability in humans, Food Research International, 108, pp. 530-538.

28. Sadin R., Chegini G.-R., Sadin H., 2014. The effect of temperature and slice thickness on drying kinetics tomato in the infrared dryer, Heat Mass Transf., 50, pp. 501-507.

29. Kaleta A., Górnicki K. (2010), Some remarks on evaluation of drying models of red beet particles, Energy Conversion and Management, 51(12), pp. 2967-2978.

30. Taheri-Garavanda A., Rafieea S., Keyhania A. (2011). Mathematical modelling of thin layer drying kinetics of tomato influence of air dryer conditions, Int. Trans. J. Eng. Manage. Appl. Sci. Technol., 2 (2), pp. 147-160.

31. Petrova Zh., Snezhkin Yu., Getmanyuk K., Dmytrenko N., Vorontsov M. (2014), Intensifying drying process with creation of functional plant compositions, Ukraine food journal, 3(2), pp. $167-174$.

32. Pazyuk V., Petrova Zh., Chepeliuk O. (2018), Determination of rational modes of pumpkin seeds drying, Ukraine food journal, 7(1), pp. 135-150.

33. Snezhkyn Yu. F., Paziuk V. M., Shapar R. A., Mykhailyk T.A., Petrova Zh. A. (2008), Yssledovanye kynetyky sushky semennoho rapsa v elementarnom sloe, Vibratsii v tekhnitsi ta tekhnolohiiakh, 1(50), pp. 93-95. 